\title{
Trust in Public Risk Management and Social Dynamics in the Case of Flood Risk
}

\section{Confianza en la gestión pública del riesgo y dinámica social en caso de inundación}

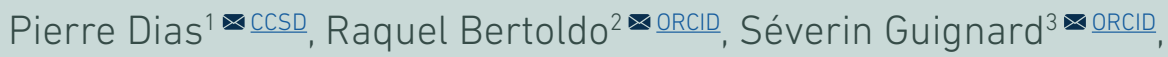 \\ Alexandra Schleyer-Lindenmann 4 CCSD
}

${ }^{134}$ Aix Marseille Univ, Université Côte d'Azur, Avignon Université, CNRS, ESPACE, UMR 7300, Avignon, France

${ }^{2}$ Aix Marseille Univ, LPS, Aix-en-Provence, France

Fecha correspondencia:

Received: May 18, 2020.

Accepted: January 22, 2021.

Forma de citar:

Dias, P., Bertoldo, R., Guignard, S., \& Schleyer-Lindenmann, A. (2021).

Trust in public risk management and social dynamics in the case of flood risk. Rev. CES Psico, 14(1), 49-63.

\section{Open access}

(c) Copyright

Licencia creative commons

Ética de publicaciones

Revisión por pares

Gestión por Open Journal System DOl: http://dx.doi.org/10.21615/ cesp.14.1.5

ISSN: 2011-3080

Comparte

\section{Abstract}

Climate change forces coastal communities exposed to floods to involve residents more actively in risk prevention, notably through official communication including behavioral recommendations. In order to improve prevention impact, this study aims to understand how inhabitants deal with this official information and integrate it into their relation to flood risk. This qualitative study is based on the theoretical postulate that the social dynamics nested in the relations between risk managers and inhabitants contributing to explain inhabitants' relationship to flood risk. These social dynamics are analysed through the type of trust granted by inhabitants to risk managers and the level of knowledge inhabitants state to have. 20 semi-structured interviews were conducted with inhabitants of a coastal city subject to flood hazards, recruited through snowballing method until saturation point. Results suggest that inhabitants who feel that they have little knowledge are prone to display social trust toward risk managers and a positive vision of communications provided on this risk, while those who are aware about floods, endorse a calculating trust based on the technical aspects of management, and eventually a form of distrust about communications delivered by public actors. These types of trust reflect a relation to flood risk embedded in the social space where individuals and groups take positions in social dynamics. In this sense and to be successful, preventive communication should consider not only the actual content of the message but also the social mechanisms that support its interpretation, in particular the trust between the messenger and the receiver.

Keywords: Risks, Risk Management, Risk Perception, Floods, Trust, Communication, Knowledge, Behaviour.

\section{Resumen}

El cambio climático está forzando a los expertos en inundaciones costeras a involucrar a los residentes en la prevención de riesgos, en particular, a través de comunicaciones oficiales que incluyen recomendaciones de comportamiento. Este estudio tiene como objetivo comprender la integración que hacen los residentes de esta información oficial en relación con el 


\section{Sobre los autores:}

1. Dr. Environmental and Social Psychology. Social and Environmental Psychology Researcher - VEDECOM Institute. Associate member ESPACE (Études des Structures, des Processus d'Adaptation et des Changements de l'Espace) Laboratory Aix-Marseille University.

2. Dr. Social Psychology. Associate Professor Aix Marseille University.

3. Dr. Social Psychology. Research at ESPACE Laboratory.

4. Dr. Developmental and Social Psychology. Associate Professor Aix Marseille University. riesgo de inundación. Se realiza un estudio cualitativo sobre el postulado teórico que considera que la dinámica social que se crea entre los gestores de riesgos y los residentes ayuda a explicar la relación con el riesgo de inundación. Estas dinámicas se analizan a través del tipo de confianza que los residentes depositan en los actores públicos de la gestión y el nivel de conocimiento que afirman tener. Se realizaron 20 entrevistas semiestructuradas con residentes de una ciudad costera expuesta al riesgo de inundaciones, reclutados mediante el método de bola de nieve hasta el punto de saturación. Los resultados sugieren que los residentes que sienten tener poco conocimiento confieren confianza social a los gestores de riesgos y una visión positiva de las comunicaciones sobre este riesgo; mientras que los que sienten tener mucho conocimiento sobre las inundaciones apoyan una confianza calculadora sobre los aspectos técnicos de la gestión y una visión negativa de las comunicaciones. Estos tipos de confianza reflejan una relación con el riesgo de inundación anclado en el espacio social donde los grupos toman posición en la dinámica social. En este sentido, para ser eficaz, la comunicación preventiva debería tener en cuenta no solo el contenido real del mensaje sino también los mecanismos sociales que apoyan su interpretación, en particular la confianza entre el mensajero y el destinatario.

Palabras claves: Riesgos, Gestión del Riesgo, Percepción del Riesgo, Inundaciones, Confianza, Comunicación, Conocimiento, Comportamiento.

\section{Introduction}

Climate change forces coastal cities exposed to more frequent flooding to increase their risk management effort, by anticipating disasters and more actively involving residents in risk prevention (Dauphiné \& Provitolo, 2007).

In general, public actors of risk management (hereafter "risk managers") count on communication (for example through official information leaflets) to convey information and instructions to the inhabitants of a territory, so that they can adopt appropriate prevention behaviours (Sjöberg, 2001). However, it is observed that inhabitants of the same territory do not all adopt the same behaviours when faced with natural risks (Weiss et al., 2011). One of the possible reasons is that communications made by risk managers are not received in the same way by all residents. What people already know and do, can lead them to reinterpret or even oppose official information and recommendations (Joffe, 2003). Indeed, the influence of preventive communication on attitudes and behaviours does not only depend on its content, but also on the knowledge and meanings that inhabitants mobilize in this situation (Petts, 1997). In addition, literature has long shown that communication's influence depends also on the judgment made about its source (Mills \& Aronson, 1965). The evaluation carried out during this judgment can be objectivated through relationships of trust or mistrust (Quéré, 2001). Trust in risk managers has been identified as an important variable in relation to flood risk perception by Kellens, Terpstra and De Mayer (2013), who also express the need for more studies on the effect of risk information on people's behaviour.

In this sense, we propose that the trust granted by inhabitants to risk managers could take a central place for understanding the interpretation of prevention messages and the adoption of behaviours that result from it. Trust is fundamentally relational (Engdahl \& Lidskog, 2014), because it defines faith placed by somebody in someone (self or others) or something (the situation). Based on the work by Giddens (1987), who studied the reaction of individuals to the uncertainty inherent in the environment, trust can be seen as a mechanism to reduce the feeling of vulnerability linked to uncertainty in 
Pág 51

In this paper, we postulate that to understand social dynamics between risk managers and inhabitants, through the study of trust, is central to explain the interpretation (adoption or not) of the recommended behaviour. the face of risks, by putting an end to the questions about skills and intentions of risk managers. Trust is therefore also related to one's own perceived level of knowledge (or feeling of uncertainty) and to the confidence granted to someone else to either compensate a lack of knowledge or confirm one's own knowledge and thus reduce uncertainty (Engdahl \& Lidskog, 2014).

Then, how does trust influence the interpretation of communications on flood risk? In this paper, we postulate that to understand social dynamics between risk managers and inhabitants, through the study of trust, is central to explain the interpretation (adoption or not) of the recommended behaviour. This work builds on previous comparative analyses that demonstrated a stronger reliance in local risk management in southern France than in the Italian Apennines (Bertoldo et al., 2020). The Italian inhabitants, vulnerable to important seismic hazards, are distressed by the lack of preventive action from local authorities and express low trust; while French participants express more trust in authorities for managing a risk they regard as minor. In our study, we observe more closely the case of coastal flood risks in southern France. These residents have their own, sometimes experiential, knowledge and representation about flood risk (Joffe, 2003), and we suppose that this perceived level of knowledge also shapes the trust relation towards the risk managers. The reception of official prevention communications by inhabitants thus necessarily involves their relationship with risk managers, expressed through the way people trust them (or not). We thus study the relation to flood risks as a social construction linked to the transactions of trust between residents and public actors as social groups. This approach has the advantage of putting psychosocial mechanisms of relationships between individuals at the center of the reflection. This allows us to propose new avenues for understanding how inhabitants deal with the official information and integrate it into their relation to flood risk, in order to improve communication's impact.

\section{Theoretical framework}

\section{Communication by public risk managers towards inhabitants}

The interpretation of risk communication, as conveyed by risk managers to inhabitants, plays a role of prime importance in understanding how the inhabitants perceive and experience this risk. Joffe (2003) shows that explanations and judgments about risk are not made in individual minds, but in the exchange between people and institutions. Knowledge, representations and risk-related behaviours are woven into social and relational dynamics that also rely on representations we attribute to other groups, e.g. those charged with the management of natural risks (Bertoldo et al., 2020). The relation to risk is thus mediated by psychological factors, linked themselves to the social dynamics of relationships between individuals and groups, in other words, their social positioning. Joffe and Orfali (2005) emphasize that the way in which people receive a prevention message is not only motivated by a need for clear information, but also by a need for psychological protection. In this sense, the perception of risk is often accompanied by biases, as e.g., the optimism bias (Peretti-Watel, 2003), which consists in estimating a greater vulnerability for others than for oneself. To put it another way, individuals tend to privilege information that they consider protective and rewarding for them, according to what they already know and do (Breakwell, 2001), and according to the relationship they have with the communication transmitter (Slovic, 1999). Overall, individuals tend to interpret information with psycho-social biases according to the social relationship they entertain with other stakeholders. 
In general, the official communication tends to be positioned as a hegemonic discourse (Castro \& Mouro, 2016) conveying knowledge which should be shared and applied by all. A hegemonic discourse implies an asymmetry in the social relationship between the experts on the one side, who hold the "good" knowledge and the audience on the other side, whose knowledge is not considered.
Communication by public actors to residents often results in "expert" speech to "audiences" (Barnett et al., 2012), thus establishing a hierarchical relation between the two groups. For public actors, communication campaigns exist to compensate an alleged lack of information among the inhabitants (Bauer et al., 2007), while integrating territorial issues (Poumadère et al., 2015). In general, the official communication tends to be positioned as a hegemonic discourse (Castro \& Mouro, 2016) conveying knowledge which should be shared and applied by all. A hegemonic discourse implies an asymmetry in the social relationship between the experts on the one side, who hold the "good" knowledge and the audience on the other side, whose knowledge is not considered.

However, the inhabitants are not only an aggregate of people that would require to be informed, "the audience", but they are also a collection of individuals who hold their own knowledge and concerns. In these conditions, where vernacular knowledge of inhabitants is rarely considered (Castro \& Batel, 2008; Batel \& Devine-Wright, 2014), it seems that beyond the objective content of the communication, the selection of protective and valuable information by the inhabitants depends essentially on the social relationship between public actors and inhabitants. As Sjöberg (2001) points out, trust plays a special role in this relationship since it influences the positioning of the different stakeholders and the retrenchment of their opinions.

\section{Residents' trust in risk managers}

A review of the literature by Earle (2010) on the role of trust in risk management, highlights the existence of a consensus around a general model with two forms of trust. Each of these trust forms is linked to a specific dimension. The first type is social or relational trust, whereas the second type is calculative trust (Rousseau et al., 1998 cited by Earle, 2010). Social/relational trust refers to the perceived moral intentions of the other. In this case, trust is thus based on a judgment which can be influenced by social relationships: if somebody judges that the intentions and values of the other are congruent with his/her own, the other is judged to be trustworthy. Calculative trust refers to perceived abilities. In this case, the technical aspects of the risk situation predominate, and the procedures and means put in place are deemed to be relevant. These two forms of trust reflect the two fundamental dimensions of social judgment: evaluation of the intentions and behaviours of the other (Fiske et al., 2007).

These two forms of trust do not differ in terms of their "effectiveness", since they both participate in accepting vulnerability, either according to the source that manages the risk, or according to the actions and techniques implemented (Earle et al., 2007). However, the way in which information is perceived and the practices put in place by inhabitants to deal with the risks may differ. In fact, the interpretation of the communication conveyed by risk managers does not only depend on its content, but also on the trust that the inhabitants have about the source (human aspect) or on the tools employed (technical aspect) (Engdahl \& Lidskog, 2014). Siegrist et al. (2005) recall that trust in managers, or in material protections, contributes in both cases to reduce the feeling of vulnerability when faced with risks. But as the mechanisms involved are different in the two cases, we assume that the resulting relationships to risk should also be different.

Thus, we propose to explore how these two types of trust, this psychological mechanism developing in social relationships, explain the perception that residents have of flood risk communication. To go further, the predominance of one of these two types of 
Pág 53

To observe the relationship between vernacular and official knowledge allows to understand how these differences of knowledge play a role in risk response by people. This approach allows enriching conceptions of preventive communications and behaviours (Grothmann \& Reusswig, 2006; Kellens, Terpstra, \& De Meyer, 2013; Weichselgartner \& Pigeon, 2015) by putting at the center of our understanding psychosocial mechanisms such as trust as the result of social relations between individuals and risk managers. trust (relational versus calculative) should depend on the judgment of communication made according to the knowledge of individuals (Fiske et al., 2007). It is therefore a social relationship where vernacular knowledge of people can be opposed to official knowledge (Poortinga \& Pidgeon, 2004).

In this way, we can make the following general hypotheses:

- Inhabitants who do not have a strong feeling of knowledge might rather display a relational trust with a judgment on the moral values mobilized in communications, and ultimately be more interested in the intentions of risk managers.

- On the other hand, inhabitants who are convinced of their knowledge would rather display calculative trust with a judgment on the technical aspects of communications, and ultimately be more interested in the tools proposed by risk managers.

To observe the relationship between vernacular and official knowledge allows to understand how these differences of knowledge play a role in risk response by people. This approach allows enriching conceptions of preventive communications and behaviours (Grothmann \& Reusswig, 2006; Kellens, Terpstra, \& De Meyer, 2013; Weichselgartner \& Pigeon, 2015) by putting at the center of our understanding psychosocial mechanisms such as trust as the result of social relations between individuals and risk managers.

\section{Methodology}

\section{Site and participants}

The study is carried out with residents of Port-Saint-Louis-du-Rhône, a town located on the Mediterranean French coast in the extension of the Camargue on the eastern edge of the Rhône. Its territory is classified by the French State as a TRI (Territoire à Risques importants d'Inondation - Territory with high flood risks), meaning that important economic, social or human stakes are exposed to a high inundation risk at present. In Port-Saint-Louis-du-Rhône, over $82 \%$ of the territory is exposed to marine flooding risks (Figure 1). In case of flooding, the near totality $\left(99 \%^{1}\right.$ ) of the population would be impacted by the inundation. The economy of Port-Saint-Louisdu-Rhône is based on three major areas: agricultural production, its harbor activity with the Gulf of Fos Harbor, and the industrial activities of warehouses and factories induced by the harbor. All of these are at stake in case of a coastal inundation. The number of inhabitants is close to 8500 , the median income around $18,000 €$ / year, the average age 40 years and the poverty rate close to $20 \%{ }^{2}$. In France, the mayor of the city is in charge of preventive information and communication about risks in his/ her community, and in case of flooding, he/she is the Director of Relief Operations, assisted by the Commander of the Operations, in general a fire fighter, and his/her deputy for risk management (CERPI, 2020). Local authorities are therefore the first in line concerning risk communication and risk management. 

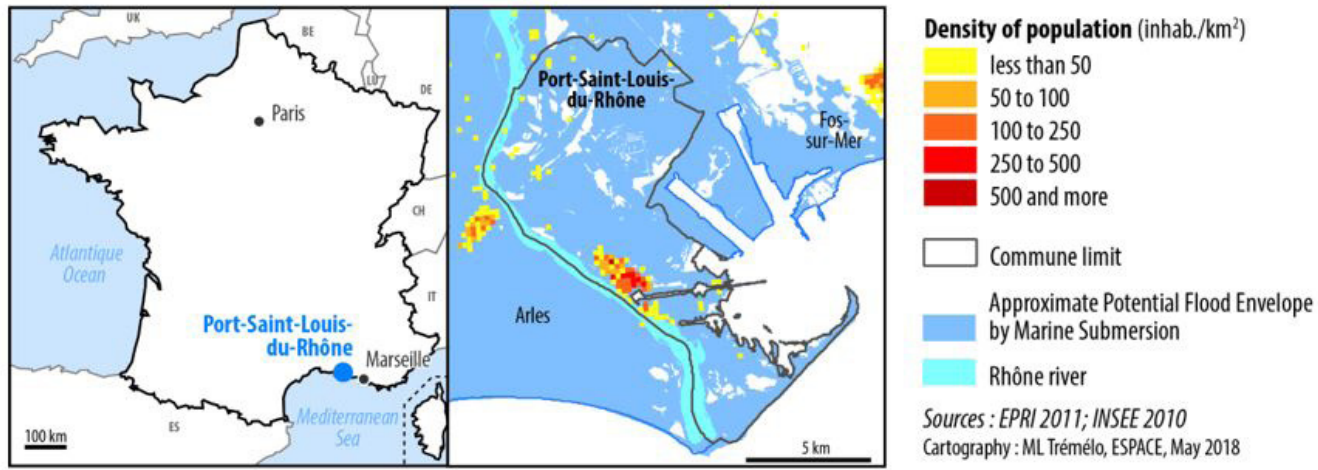

Figure 1. Potential flooding by marine submersion for Port-Saint-Louis-du-Rhône

We conducted a qualitative study both based on an inductive approach (which seeks to explore the data collected) and deductive approach (which seeks to verify theoretical hypotheses). However, we did not seek to interview a representative sample of this population, but to build a survey in order to collect the diversity of opinions among the inhabitants about flood risk. We interviewed residents of this town with the aim of having a balanced sample in terms of age, sex, occupations and places of residence, in order to obtain different socio-demographic profiles. This has the advantage of presenting a variety of individual profiles while allowing them to be compared by their common geographic locations.

Our sample thus consists of 13 men and 7 women with an average age of 58 years (SD: 15 years). Among the occupations encountered are 2 seafarers, 3 dockers, 5 liberal executives, 5 small traders, 2 artisans and 3 artists. 11 of these people lived in the city center and 9 in the peripheral districts close to the center ${ }^{3}$. All interviewees have lived in this city for over 20 years.

\section{Tools and Procedures}

Our study started with a first meeting at the town hall to present the study. We then contacted individuals belonging to a variety of local associations by telephone and invited them to participate in a university study on flood risks through semi-structured interviews. The interviews were conducted individually, face to face with the interviewer, and took place in a place of convenience for interviewees, at their home or workplace. On average, these interviews lasted one hour. Interviewees were then asked to indicate one or two other potential participants (snowballing system). These interviews were carried out until the saturation criterion was reached (Savoie-Zajc, 1996) i.e. until the information gathered through interviews became redundant. This was the case in Port-Saint-Louis-du-Rhône after 20 interviews.

At the beginning of the interview, the participant was informed about anonymity and data protection and invited to sign the informed consent leaflet, approved by the committee of research ethics of our university. Then, the interviewee was invited to express himself/herself freely on his/her town and on the risks of flooding in a general introductory phase. During the interview, the investigator reframed the discussion to deepen the discourse or the themes which were not spontaneously approached. This framework gives the advantage of being able to collect the meaning that people give to their own experiences (representations, values, etc.), while subscribing to specific themes (Quivy \& Van Campenhoudt, 1995). 
The interviews were based on an interview guide with three mains sections:

1. The first part sought to identify the knowledge that the inhabitants have of the floods on their territory under several dimensions: the conscience that there is a risk, the methods to manage it and the knowledge, meanings/emotions which are linked to it.

2. The second part explored the inhabitants' flood experiences. The aim was to address the past events encountered and the anticipation of potential future risk.

3. Finally, the third part sought to understand the nature of the trust placed in the public risk managers who set up official communications in this territory. It is also to observe how these communications, and management in general, are evaluated, experienced and felt by the inhabitants.

It is the articulation of these three themes which makes it possible to test our hypothesis on the influence of the type of trust (social/calculative) in the reception of communications made by flood risk managers.

\section{Data Analysis}

After transcription, a qualitative and thematic analysis of this corpus was carried out manually in order to meet the objective of identifying relations and meanings associated with flood risks. This thematic analysis was based on a back and forth movement of reading and comparing between our initial categories of interest (the sections of our interview guide) and the meaning and topics emerging from the data (combined top-down and bottom-up approach).

Content analysis led to three main themes emerging from the data:

- First, the content analysis revealed the description of the perceived level of vulnerability.

- The second theme shows how the participants frame their perceived level of vulnerability by describing their relations with local authorities and the trust they put, or not, in them.

- Finally, the third theme, knowledge, shows that participants associate their level of knowledge about the floods and their territory to the topic of trust.

These three main themes thus organize our analysis of the relationship regarding flood risk: the perception of vulnerability, the role played by social dynamics in trust, and the overlap between knowledge and type of trust. Across these three themes, social and calculative trust will be presented independently in order to identify their respective ins and outs with perceptions emerging from the discourses ${ }^{4}$. 


\section{Results}

\section{A strong feeling of low vulnerability}

First, we note that the complete sample without exception emphasize that they were not afraid of the risk of flooding in their territory. Indeed, although the existence of flood risk (by sea, river or rain) is perceived by all, the feeling of vulnerability in the face of this risk is very low among all the people interviewed:

"So, tomorrow, if there is water, there is water, I will lose my cars, I will lose my cars, never mind. The insurances will have to work. We pay them for it, it's unfortunate to say this, but so it is. Moreover, I know I have everything I need to live on the upper floor, and if it rains tomorrow never mind, dear. There you are, I don't really fear natural risks." (Man, 30 yrs)

"Even in the worst hazards, there is no real risk of drowning, nothing at all of this. There might be about $10 \mathrm{~cm}$ of water in some houses, but that were about the biggest floodings we ever had. [...]. With the situation of our neighbourhood in relation to the sea, I don't think there is a lot of risk here. I was never really scared here, because except for material damage, or in my garden, when there was too much water, the flower bulbs came out again or something like that, but no, I was never afraid here." (Man, 69 yrs)

Although there is a consensus, a shared perception among the inhabitants regarding their very low level of vulnerability and a real lack of concern about flood risk, results show that this psychological process can be related to different mechanisms of trust, displaying the importance of social dynamics.

"I had the possibility to leave, I could have sold and lived somewhere else, but no. I like it here a lot. I hear the birds when I get up in the morning. I can spend the day without hearing a single car noise. That's it. I am not afraid [laughing]. The water doesn't scare me. [...]. No, people are not scared here. No, they aren't afraid of anything. Otherwise they would have left." (Women, 51 yrs).

Although there is a consensus, a shared perception among the inhabitants regarding their very low level of vulnerability and a real lack of concern about flood risk, results show that this psychological process can be related to different mechanisms of trust, displaying the importance of social dynamics.

\section{Perception of low vulnerability linked to social trust}

In the case of about half the sample (11 interviewees) the low level of vulnerability is articulated to social trust in the local actors of flood risk management. Here, the discourses highlight the good intentions of public local actors and emphasize, for example, the benevolence of the municipality. This trust is thus placed on people who, by their social status, are in charge and are supposed to be knowledgeable:

"So, it's true that ... no, well I, I trust the municipality. Personally, I think people here do not live in fear of that, no, no. [...] So afterwards, what can we do. I guess it's the mayor who's going to give instructions. I would place my trust like this, I tell myself, like this." (Women, 69 yrs)

"I think they all did what they could, I think they have thought about what could happen, but really, we've never been in big trouble here, never. [...]. I trust my city, my mayor, everything. I think everything is fine, but you feel that there is a lack of money. Otherwise, the mayor we have is good." (Women, 85 yrs). 
Participants who display social trust in management actors tend to express at the same time a feeling of lack of knowledge about flood risks on their territory. All these speeches could be characterized by the formula "I don't really know". These interviewees declare that they follow the advice given in preventive communications and adopt behaviour as instructed by official knowledge.
"I think they do what they can with the means at hand... Uh, because it's not obvious ... uh, all policies kept, huh. Whether it's the old municipality or the new one, they know how to take initiatives." (Man, 63 yrs).

\section{Perception of low vulnerability linked to calculative trust}

For the other half of the sample (9 interviewees) the feeling of low vulnerability is linked to calculative trust in public risk managers. Here, participants of the study highlight the technical aspects of managing this risk, the effectiveness of existing tools, and stress the importance of the knowledge they have themselves on the subject. In this sample, a greater distrust is also visible in relation to the intentions of public actors. In this group, calculative trust seems to be linked low social trust. Participants mention the municipality and its economic and/or political priorities that would hinder the implementation of tools that they consider effective:

"They open the umbrella, so they are under cover. If there is a problem one day, they have done their job. [...]. In the first years, everything is put into motion, everything is cleaned up and then little by little, as soon as there are more problems, the money is put elsewhere. [...]. Because now the municipality covers itself and therefore sends us the alert and, in this instance, we go and look at the PREVIMER ${ }^{5}$ map in order to have the orientation of the wind, they don't do that. [...]. They have made lots of systems to prevent flooding, towards the high school there is an expansion area so that the water can come in, with big pumps to drain it progressively. [...]. These are things we don't have. [...]. For our two neighbourhoods no, they do nothing, nothing at all." (Man, 58 yrs).

"The water pumps, they never work when needed, so necessarily there is a moment, when, well everything overflows. [...] And, then, here it is, the story of the channel: before, it emptied, and now it doesn't empty anymore, this is not due to climate change, this is because, well, there is some moron who decides that he doesn't want this is done or that is done, because he has the power, that's all. Here." (Women, 66 yrs).

"There were places where ... especially the city center, which was very strategic, because there were shops and there is Intermarché [the local supermarket], there was ... all that was flooded. So, they pumped pretty quickly. Afterwards, there are neighbourhoods that have been somewhat neglected. [...] I say that one thing, the politicians, they only move when there is something." (Man, 60 yrs)

Furthermore, it appears that these two types of trust, social and calculative, are also linked to the knowledge and the experiences that individuals already have.

\section{Perception of poor knowledge and social trust}

Participants who display social trust in management actors tend to express at the same time a feeling of lack of knowledge about flood risks on their territory. All these speeches could be characterized by the formula "I don't really know". These interviewees declare that they follow the advice given in preventive communications and adopt behaviour as instructed by official knowledge:

"After all, I am not a specialist, I don't understand anything of it. Well, here, I mean, there are engineers who make the plans, who do the ... I mean here. You ask me, how do you pull a hair out, I'm telling you. But after, the rest, I don't understand 
In these speeches, we also observe spontaneous comparisons with the behaviour of "other" inhabitants and the criticism of those who do not follow official directives. This highlights the importance of the trust attributed to the official communications. anything, I don't know, huh. [...] I mean, if they are engineers, it is not for nothing. (laughs) They must be useful for something (laughs) there. So, afterwards, no, everyone must respect. Now, after he says to me, it's not in ... I don't understand anything, I don't know, it's not within my abilities. [...] Well... uh, yeah, I think I'm stupid and disciplined myself." (Women, 61 yrs).

"For me the phenomenon I do not, I do not understand it, because I know nothing about it. [...] Well, I don't know, I don't know nothing, precisely. Because I don't know anything about it. So, I'm not going to put any ideas forward. So, it's true that... well I trust the municipality. [...] I think that... uh, the municipality that is in place here, knows what it has to do [...]. There are plans to... uh, for... uh, to shelter people..., and then, for their safety and all that. No, they do their ... they do their job [...]. Everyone who works knows what to do and it's too easy to criticize civil servants." (Women, 69 yrs)

"Ah! Yes Yes Yes. If they say to listen to the radio, at least in this case, I think that to be kept informed of ... since, when we are in a flood situation, we often stay locked up at home, which is normal and so, by consequence, we have to stay tuned, yes. Often, I don't know, it's on TV, often there was the prefecture, I think that gave instructions via a local radio and that, by consequence, was quite practical. [...] There are basic behaviours to respect." (Man, 22 yrs)

In these speeches, we also observe spontaneous comparisons with the behaviour of "other" inhabitants and the criticism of those who do not follow official directives. This highlights the importance of the trust attributed to the official communications:

"The municipality sets up the zones, the possibilities of flooding, the signs prohibiting to pass, this and that, but, they, they don't care at all, they pass, they don't care at all, that's it. Because for them there is no danger. [...] If it was me, I would not pass. (laughs) Because yes, anyway, that's it. If I am told that there is a risk, I will not do it. [...] That is to say, yes, they are used to it, they have always lived there like that. So, they know that it is necessary... that... the municipality puts up signs, but they do not respect it, because they have their own experiences and they believe that there is no risk. But too bad, it's their problem, it's not mine. Too bad for them (laughs). Then anyway, I imagine they know what they're doing (laughs)." (Women, 69 yrs)

"But to live happily, it is sometimes better to be less informed. [...] As I told you earlier, to be informed is to take responsibility and that does not make me happy. [...] Afterwards, we are often... depending on the storms, we have a PPRI [protection plan against inundations] in Port-Saint-Louis and we are categorized as in a coastal flooding zone, and now it's national, we are finally told that we must not trespass, we receive phone calls from our municipality during storms, that we should not access, for example, Napoleon Beach. [...] And this is where I tell my tourists, when they come here and when it is during the strong wind and when the warning sign is placed: "it is not there for nothing". I forbid them to venture in the countryside and up to Napoléon beach." (Women, 49 yrs).

\section{Perception of strong knowledge and calculative trust}

Conversely, interviewees who display calculating trust in the management actors tend to express the feeling of a strong knowledge of flood risks and of their territory. All these speeches could be characterized by the formula "we know, we are used to 
Pág 59

Thematic analysis of interviews conducted with 20 inhabitants of the city of Port-Saint-Louis-du-Rhône, a territory particularly subject to the hazards of floods and submersions, allowed to highlight the importance of trust and precisely how two types of trust, relational or calculative, explain the perception that residents have of flood risk communication. it". People in this group declare that they do not follow prevention communications. They adopt behaviours according to their own technical knowledge, stressing that these are only rarely known by public management actors:

"This is bullshit because now, the slightest thing, everyone is crying wolf and hey, it's done once, 2 times, 3 times, 10 times. It's not more than usual, sometimes it's even less. And the day when there is really a ball, nobody will believe it. [...] We, we know, we are used to it. We see it coming in time. So, we are not surprised, we have never been surprised, no [...] So we have no surprise at all. [...] I say that they are dumb, because they have knowledge, they are full of diplomas. But now, they do their thing for them. [...] No, there is no exchange. No. [...] Afterwards, and that is the problem, now everyone covers themselves. The mayor, he covers himself so as not to be bothered. The sub-prefect, he covers himself so as not to be bothered by the prefect. The prefect, he covers himself so as not to be bothered by the Minister. Everyone covers up. [...] No, no, there. We know we don't risk anything." (Man, 60 yrs)

"We know it. You know that when there are big blows from the south, the water goes up on the beach, it overflows, and all around the sheds is drowned. [...] You know when you're used to since childhood, afterwards, you don't mind, no. We know that every winter, in principle, we take a bath. Here. [...] Well you know, people, they are used to here in Saint-Louis, there are still old families, all those who live on the banks of the Rhône, they are only old families. They know very well what's going on, that, that's it. I'm telling you, it's a matter of habit." (Man, 65 yrs).

"We know it. They're calling us so that we don't go to the sheds. They asked to do this otherwise they destroyed our sheds. Well, we kept the sheds, we said that indeed, when this happens, we do not go. Even if we go, well, we take our responsibilities. [...] Nothing can happen to me in the Rhône [river], I know it sufficiently well. [...] When you know that you are in a place like us in the shed, we don't get caught because we know we are in a hole and we put everything on higher level. [...] Or else, as soon as they call us; I'm getting a call, I don't know, it is... there's the number that says 'Beware of flooding. Attention risk of wind, risk of rain.' It's good because well, afterwards, you have to respect. People ... no, we are fine." (Man, 60 yrs).

To complete our results, we do not observe differences between the two types of group identified in terms of age, sex, profession or location in town.

\section{Discussion and Conclusions}

This study aims to understand inhabitants' relation to flood risk by analysing social dynamics between residents and risk managers as revealed through the trust placed by the former in the latter concerning risk communication. It also aims to qualify the relation between social and calculative trust and residents' perceived level of knowledge. Thematic analysis of interviews conducted with 20 inhabitants of the city of Port-Saint-Louis-du-Rhône, a territory particularly subject to the hazards of floods and submersions, allowed to highlight the importance of trust and precisely how two types of trust, relational or calculative, explain the perception that residents have of flood risk communication. Particularly, examining the relationship between the knowledge and experiences of the inhabitants and their trust in communications enabled us to validate our two hypotheses. Individuals who do not have the feeling of knowledge display a stronger relational trust with a judgment on the moral values mobilized in communications, and ultimately are more interested in the intentions 
However, the feeling of having little or a lot of knowledge about floods clearly relates to the type of trust that is granted to public management actors. Here again, two sets of contents are meaningful with relation to risk: when individuals feel that they have little knowledge on the subject, they tend to develop social trust based on a positive assessment of the public actors' status, their intentions and their values. of risk managers. On the contrary, individuals who are convinced to have a lot of knowledge show more often calculative trust with a judgment on the technical aspects of communications, and ultimately are more interested in the tools proposed by risk managers.

Results show that, despite their different levels of knowledge and experience, all interviewees without exception display a very low feeling of vulnerability regarding flood risks in their territory. On a macro-level, these observations are coherent with an important local cultural dimension: the generalized strong feeling of closeness to nature which prevails in Port-Saint-Luis-du Rhône since its existence (Charrière et al., 2004). Natural hazards are traditionally lived as inevitable, usual and non-alarming. This is visibly not in tune with the official position of risk information. On a micro-level, however, results show that this feeling of low vulnerability can be related to different types of trust, distributed about evenly in the sample and representing two types of contents revealing meaningful interpretation of risk communication: on the one hand, people who place their trust in public actors (relational, social trust) and on the other hand, people who place their trust in the technical aspects of management (calculative trust). Surprisingly, although people seem to endorse different types of trust (calculative or relational) with regard to public management, both are related to the same absence of a feeling of vulnerability. Indeed, placing trust in public risk managers or in oneself and technical devices both combine with a low feeling of vulnerability. In other words, trust participates in self-protection, either reaffirming existing knowledge or reassuring in case of absence of knowledge (Breakwell, 2001; Joffe \& Orfali, 2005; Siegrist et al. 2005).

However, the feeling of having little or a lot of knowledge about floods clearly relates to the type of trust that is granted to public management actors. Here again, two sets of contents are meaningful with relation to risk: when individuals feel that they have little knowledge on the subject, they tend to develop social trust based on a positive assessment of the public actors' status, their intentions and their values. When they feel they have a lot of knowledge about the risk, they tend to develop calculative trust based on the technical aspects of management that they judge in comparison with their own knowledge. Based on the level of knowledge, residents position themselves in social space and condition their type of trust placed in public risk managers. The reception of communications and the behaviours adopted could therefore be considered as social positioning. In this sense, Castro and Mouro (2016) show that individuals can adopt a normative discourse on risks which reproduces the thought of "experts", or an epistemic discourse which challenges this thought through local knowledge. Our study follows these conclusions, which highlight the existence of two different kinds of social relationships between the inhabitants of a territory and the public actors of risk management, framing the existence of different perceptions, attitudes and behaviours towards flood risk.

In a meaningful logic, the two types of trust are related in a coherent way to different receptions of preventive communication. Individuals who have the feeling of having little knowledge and who display social trust in risk managers such as the mayor, have at the same time a positive vision of the communications conveyed by this source. They declare to listen and follow the instructions, implementing the recommended behaviours. Conversely, individuals who feel they have a great deal of knowledge about floods and display calculative trust are more interested in the technical aspects of communications. They therefore tend to rely on their own knowledge and declare that they do not follow official recommendations if they consider them irrelevant according 
Pág 61

To conclude, these results underscore the importance of psychosocial processes which orientate thinking and acting when faced with risk situations. It is important for prevention and protection policies to consider the social construction of risk as much as its physical aspects and constraints. This involves considering the social mechanisms underlying the psychological process of trust when developing official communication, rather than seeking to build trust through communications. For example, vernacular knowledge or local voices could take a place in collective risk management, opening thus new avenues for exchanges and favoring mutual trust. to their own knowledge. These results suggest that the effect of the communication carried out by risk managers does not only depend on its content, but also on the trust - or mistrust - that the inhabitants place in the source (social aspect) or in the tools (technical aspect). Thus, the behaviour of residents faced with flood risks does not only depend on the knowledge that public actors seek to enrich by official communications, but above all upon underlying psychosocial factors such as trust.

As a perspective, new questions could be relevant, for example, to verify whether the claim for local knowledge can reflect a strategy allowing to accept technical expertise without self-devaluing a social position and one's social identity. Strong knowledge about flood risk could lead to greater self-confidence, which would minimize the need to have social trust in others. In other words, developing a calculative confidence is certainly linked to a form of pre-existing expertise in the territory and to a form of claim which can induce mistrust towards the communications of public actors. It would be interesting to replicate this type of analysis in different geographical areas to check whether the social and spatial characteristics of a territory can influence these results. In addition, a larger sample would also make it possible to identify the factors that explain the adoption of a particular type of trust, such as the involvement of individuals in floods. A quantitative study would allow to test the relative weight of these various factors, such as for example the adaptive capacity resources that affect both perceived and real level of vulnerability or the influence of social and environmental identity on the adaptation of a particular type of trust.

To conclude, these results underscore the importance of psychosocial processes which orientate thinking and acting when faced with risk situations. It is important for prevention and protection policies to consider the social construction of risk as much as its physical aspects and constraints. This involves considering the social mechanisms underlying the psychological process of trust when developing official communication, rather than seeking to build trust through communications. For example, vernacular knowledge or local voices could take a place in collective risk management, opening thus new avenues for exchanges and favoring mutual trust.

\section{Acknowledgments}

This work is a contribution from the Labex OT-Med ( ${ }^{\circ}$ ANR-11-LABX-0061) and received funding from the Aix-Marseille University Excellence Initiative - A*MIDEX, a French government program "Investments for the Future". This project is also funded by the European Union through the European Regional Development Fund (FEDER) (DIGUE2020 project). Thank you to Marie-Laure Trémélo for research support.

\section{References}

Barnett, J., Burningham, K., Walker, G., \& Cass, N. (2012). Imagined publics and engagement around renewable energy technologies in the UK. Public Understanding of Science, 21(1), 36-50. https://doi.org/10.1177/0963662510365663

Batel, S., \& Devine-Wright, P. (2014). Towards a better understanding of people's responses to renewable energy technologies: Insights from Social Representations Theory. Public Understanding of Science, 24(3), 311-325. https://doi. org/10.1177/0963662513514165

Bauer, M., Allum, N., \& Miller. S, (2007). What can we learn from 25 years of PUS survey research? Liberating and expanding the agenda. Public Understanding of Science, 16, 79-95. https://doi.org/10.1177/0963662506071287 
Bertoldo, R., Tanga, R., Dias, P., Guignard, S., \& Schleyer-Lindenmann, A. (2020). Calculative and relational trust in the management of coastal floods and earthquakes: a comparative study. PsyEcology. Bilingual Journal of Environmental Psychology, 11(2), 193-213. https://doi.org/10.1080/21711976.2020.1734398

Breakwell, G. M. (2001). Social representational constraints upon identity processes. In K. Deaux, \& G. Philogène (Eds.), Representations of the social: Bridging theoretical traditions (271-284). Blackwell Publishing.

Castro, P., \& Batel, S. (2008). Social representation, Change and Resistance: On the difficulties of generalizing new norms. Culture \& Psychology, 14, 475-497. https:// doi.org/10.1177/1354067X08096512

Castro, P., \& Mouro, C. (2016). Imagining ourselves as participating publics: An example from biodiversity conservation. Public Understanding of Science, 25(7), 858872. https://doi.org/10.1177/0963662515581303

Charrière, J.L., Gontier, C., Meyer, M., Picon, B., \& Schleyer-Lindenmann, A. (2004). (Eds.) Port-Saint-Louis-du-Rhône ou le génie de l'adaptation. Aix-en-Provence : Edisud.

CERPI (Centre Européen de Prévention du Risque d'Inondation). (2020). Gestion d'une Crise d'Inondation : suivez le guide! Consulted on https://www.ecologie.gouv.fr/ sites/default/files/guide\%20gestion\%20crise\%20inondation\%20CEPRI.pdf

Dauphiné, A., \& Provitolo, D. (2007). La résilience : un concept pour la gestion des risques. Annales de géographie, 654(2), 115-125. https://doi.org/10.3917/ ag.654.0115

Earle, T.C. (2010). Trust in risk management: a model-based review of empirical research. Risk Analysis, 30(4), 541-574. https://doi.org/10.1111/1.15396924.2010.01398.x

Earle, T. C., Siegrist, M., \& Gutscher, H. (2007). Trust, risk perception, and the TCC model of cooperation. In Siegrist, M., Earle, T. C., Gutscher, H. (eds). Trust in Cooperative Risk Management. London: Earthscan. https://doi.org/10.1080/10807030802012477

Engdahl, E., \& Lidskog, R. (2014). Risk, communication and trust: Towards an emotional understanding of trust. Public Understanding of Science, 23(6), 703-717. https://doi.org/10.1177/0963662512460953

Fiske, S.T., Cuddy, A.J.C., \& Glick, P. (2007). Universal dimensions of social cognition: Warmth and competence. Trends in Cognitive Sciences, 11, 77-83. https://doi. org/10.1016/i.tics.2006.11.005

Giddens A. (1987). La constitution de la société. Paris: PUF. https://doi.org/10.3406/ polix.1988.2014

Grothmann, T., \& Reusswig, F. (2006). People at Risk of Flooding: Why Some Residents Take Precautionary Action While Others do not. Natural Hazards, 38, $101-$ 120. https://doi.org/10.1007/s11069-005-8604-6

Joffe, H. (2003). Risk: from perception to social representation. British Journal of Social Psychology, 42, 55-73. https://doi.org/10.1348/014466603763276126

Joffe, H., \& Orfali, B. (2005). De la perception à la représentation du risque : le rôle des médias. Hermès, La Revue, 41, 121-129. https://doi.org/10.4267/2042/8962

Kellens, W., Terpstra T., \& De Maeyer, Ph. (2013). Perception and Communication of Flood Risks: A Systematic Review of Empirical Research. Risk Analysis, 33(1), 24-49. https://doi.org/10.1111/j.1539-6924.2012.01844.x

Mills, J., \& Aronson, E. (1965). Opinion change as a function of the communicator's attractiveness and desire to influence. Journal of Personality and Social Psychology, 1(2), 173-177. https://doi.org/10.1037/h0021646

Peretti-Watel, P. (2003). La Sociologie du risque. Paris: Armand Colin. 
Petts, J. (1997). The public-expert interface in local waste management decisions: experts, credibility and process. Public Understanding of Science, 6, 359-381. https://doi.org/10.1088/0963-6625/6/4/004

Poortinga, W., \& Pidgeon, N.F. (2004). Trust, the asymmetry principle, and the role of prior beliefs. Risk Analysis, 24, 1475-1486. https://doi.org/10.1111/j.02724332.2004.00543.x

Poumadère, M., Bertoldo, R., Idier, D., Mallet, C., Oliveros, C., \& Robin, M. (2015). Coastal vulnerabilities under the deliberation of stakeholders: The case of two French sandy beaches. Ocean \& Coastal Management, 105, 166-176. https://doi. org/10.1016/j.ocecoaman.2014.12.024

Quéré, L. (2001). La structure cognitive et normative de la confiance. Réseaux, 108(4), 125-152. https://doi.org/10.3917/res.108.0125

Quivy, R., \& Van Campenhoudt, L. (1995). Manuel de recherche en sciences sociales. Paris: Dunod.

Rousseau, D. M., Sitkin, S. B., Burt, R. S., \& Camerer, C. (1998). Not so different after all: a cross discipline view of trust. Academy of Management Review, 23, 393-404. https://doi.org/10.5465/amr.1998.926617

Savoie-Zajc, L. (1996). Saturation. In A. Mucchielli (Dir.) : Dictionnaire des méthodes qualitatives en sciences humaines et sociales. Paris: Armand Colin. https://doi. org/10.4000/communicationorganisation.1901

Siegrist, M., Gutscher, H., \& Earle, T.C. (2005). Perception of risk: the influence of general trust, and general confidence. Journal of Risk Research, 8, 145-156. https://doi. org/10.1080/1366987032000105315

Sjöberg, L. (2001). Political decisions and public risk perception. Reliability Engineering and System Safety, 72(2), 115-123. https://doi.org/10.1016/S09518320(01)00012-6

Slovic, P. (1999): Trust, emotion, sex, politics, and science: Surveying the risk-assessment battlefield. Risk Analysis, 19, 689-701. https://doi. org/10.1023/A:1007041821623

Weichselgartner, J., \& Pigeon, P. (2015). The role of knowledge in disaster risk reduction, International Journal of Disaster Risk Science, 6(2), 107-116. https://doi. org/10.1007/s13753-015-0052-7

Weiss, K., Girandola, F., \& Colbeau-Justin, L. (2011). Les comportements de protection face au risque naturel: De la résistance à l'engagement. Pratiques Psychologiques, 17, 251-262. https://doi.org/10.1016/j.prps.2010.02.002 